\title{
Introduction: changing lives and new challenges
}

\author{
Jacqueline Scott, Shirley Dex, Heather Joshi, \\ Kate Purcell and Peter Elias
}

There have been enormous changes in women's lives in the UK in the past 25 years. The proportion of women in the labour market has grown markedly; the pay gap has narrowed; notions that a woman's place is in the home have eroded further; women have overtaken men in numbers pursuing higher education; and women have made inroads into some previously male-dominated employment sectors. In other areas, earlier inequalities have proved very resistant to change, with women continuing to be more likely than men to reap adverse job-related penalties associated with childrearing and family care; conditions of part-time work continue to enhance gender inequality; and work-family or work-life balance remains very different for men and women.

In this book we examine different aspects of women and employment, and discuss how labour market experiences have not only changed the lives of women and their families, but also brought new challenges. These not only differ for women and men but also differ across the life course. Even before adulthood, young girls and boys have very different expectations and aspirations concerning their work and family lives. In the post-retirement phase, the gendered consequences of inequalities in the workplace are visible in terms of the dramatically lower pension entitlements of women who have taken 'time out' of paid work for child-raising and family care. The challenges also affect institutions. For example, employers are struggling to implement rather than just pay lip-service to family friendly policies, from childcare provision to flexible work hours; and schools and career advisory services are attempting to break down the stereotypes that contribute to the gender segregation of the labour force, including the worrying dearth of women entering careers in science, engineering and technology. Policy-makers are sometimes caught unawares by the speed with which women's work and home lives are changing, as well as the extent of change. Indeed, changing patterns of women's and men's employment and family roles have to be set in the wider context of socio-economic changes 
including demographic changes, migration processes, educational expansion, transnational labour markets, technological advances, and the global economy.

We tackle a range of questions that are relevant to understanding the changing nature of women and employment and look ahead to likely changes to come. How are women faring in the labour market in comparison to men, and how has this changed over time? What do we know and what do we need to know about how ethnic diversity impinges on equality in the workplace? How well is Britain doing on equality issues compared with other countries? Can we disentangle the influence of preferences and constraints on the different priorities of men and women concerning family and employment? What does work-family or work-life balance mean? How far do the time pressures on dual earners differ across employment sectors and class? How will migration and the enlarged European Union (EU) affect the employment opportunities of women and men in the future? The authors use both qualitative and quantitative data at local, national and cross-national levels to provide empirical evidence for how women's employment lives are changing.

The book builds on a collection of original papers given at a high profile conference hosted by the UK Women and Equality Unit. The conference celebrated the twenty-fifth anniversary of the Women and Employment Survey (WES), which was carried out in 1980 jointly by the Office for Population Census and Surveys and the Department of Employment. The main aims of the survey were to establish what factors determine whether or not women are in paid work and to identify the degree to which domestic factors, or more broadly the gender division of labour, shapes women's lifetime labour market involvement. Full information was collected about the type of work women do, their pay and conditions of employment, as well as the way women behave when in the labour market, when they leave jobs or look for work. The study also set out to determine the importance of work to women and their job priorities. It was the first time detailed work histories, covering the whole of women's lives, were collected and such data allow for analysis of how earlier events such as the timing of childbirth affects women's job transitions and career trajectories.

\section{THE CONTEXT FOR THE 1980 WOMEN AND EMPLOYMENT SURVEY}

The WES survey supported analysis that sought to investigate and understand the extent of women's labour market activity and to find out the 
reasons why women were not in the labour market (Martin and Roberts 1984). The survey was the cornerstone of a whole raft of studies that looked at questions about maternity provision, women's pay and other issues (for example, Dex and Shaw 1986; Main and Elias 1987; Wright and Ermisch 1991). These were key concerns because there had been major changes in the level and nature of women's economic activity. In addition there had been a series of legislative initiatives concerning sex discrimination, equal pay and maternity provision that were designed to address the all too glaring inequalities in employment experiences of women and men.

Large-scale social surveys, such as the 1980 Women and Employment Survey, have an invaluable role in informing research on the social and economic changes that impact upon, and shape, the way we live and work. It is important, though, to recognise that these research instruments are themselves influenced by prevailing cultural norms and contemporary perceptions of social roles.

In this book we step back to the early 1980s and reflect upon research conducted at that time, based upon the 1980 Women and Employment Survey and its predecessor, the 1968 Survey of Women's Employment. What were the gender and equality issues that preoccupied us 25 years ago? How were these shaped by social and economic trends and the changing legal environment of that time? More importantly, when the 'evidence' was interpreted and extrapolated to envisage the future, how well did we predict the changes that would take place over the next 25 years? What do the prospects for equality look like a quarter of a century on?

Two features of the UK economy stood out in the period around 1980: the move towards mass unemployment as the economy encountered fundamental restructuring from heavy, male-dominated labour-intensive physical production to an economy based upon the production and exchange of information and the provision of business and consumer services, and the strong growth in part-time working associated with the latter. It seemed quite natural to interpret these related economic developments in terms of their implications for men and women. Many men were losing full-time jobs in industries such as coal mining and steel production, vehicle production and assembly, and appeared to have little chance of regaining fulltime employment. At the same time, women's employment in part-time jobs continued to expand rapidly, albeit in fairly low-paid occupations. The combined supply-side and demand-side influences on women's labour force participation, arising from pressures to maintain family incomes and to satisfy the burgeoning demand for flexible labour in the service sector, were drawing many women back into employment after a period of family formation. 


\section{CHANGES IN THE LABOUR MARKET SINCE 1980}

In 1980 just under half of all married women and two-thirds of single women were working in employment outside the home. Just over 40 per cent of mothers with dependent children were working. The gender pay gap was just under 30 per cent.

Many changes have taken place in the labour market since 1980 . Figure I.1 shows the trends in male and female employment over the past two decades, distinguishing between those in full-time and part-time employment. The decline in male full-time employment in the late 1980s and early 1990s is distinctive, as is the growth in part-time working. Given that the rise in female labour force participation was associated with the return to paid work after a period of family formation, researchers were expressing concern that this would lead to a growing mismatch between the prior skills and work experience of these 'women returners' and the quality of the part-time work to which they were returning (Elias and Purcell 1988). While the outlook was not optimistic for women who worked parttime, policy and legislation changes over this period have ameliorated some of the potential effects that were being predicted. The European Union Part-time Working Directive, the Parental Leave Directive, and provision of day and after-school care for children have gone some way to improve working conditions of part-time jobs, and offer women returners better employment prospects that more nearly match their preferences for job security, reduced hours and better career prospects.

In retrospect, while improvements of part-time working conditions were necessary to facilitate equality, they were not sufficient to address some of the more deep-seated problems that affect men and women's opportunities in employment more generally. From the mid-1990s, full-time employment for both men and women continued to grow steadily. This is apparent in Figure I.1, which shows that for women, the growth in full-time employment from the mid 1990s onwards was stronger than the growth in parttime employment.

What research in the 1980s failed to anticipate was the subsequent large changes in the occupational structure of the economy that has had a major impact on the employment opportunities for both men and women. Some indication of the dramatic nature of these changes can be gained from Figure I. 2, in which we distinguish between the two major groups of occupations. The first of these covers Groups 1, 2 and 3 of the 2000 Standard Occupational Classification (SOC). This broad group covers managerial, professional and associate professional occupations, essentially those which are strongly connected with the growth of the 'knowledge economy' - jobs linked to the production and utilisation of knowledge rather than 


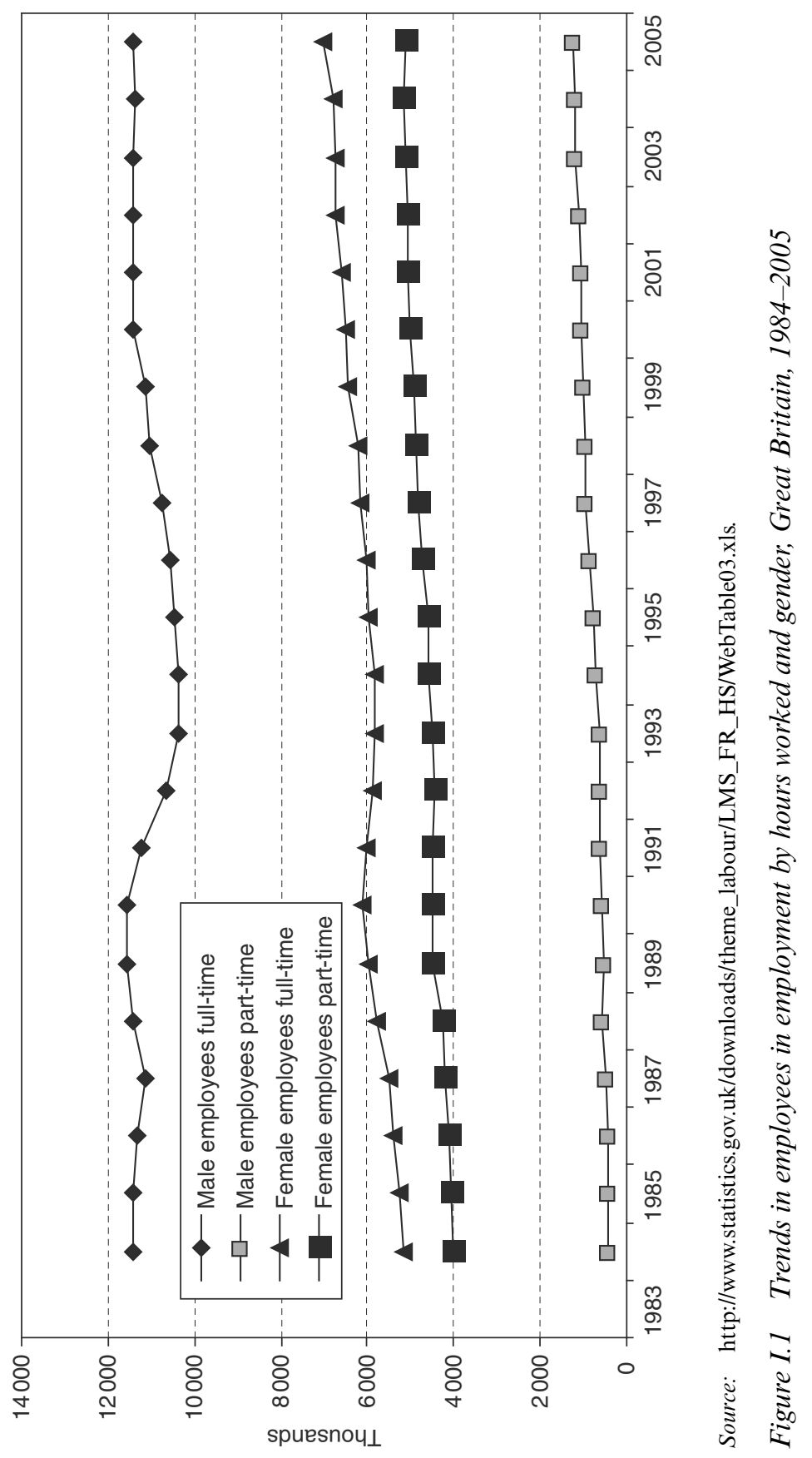




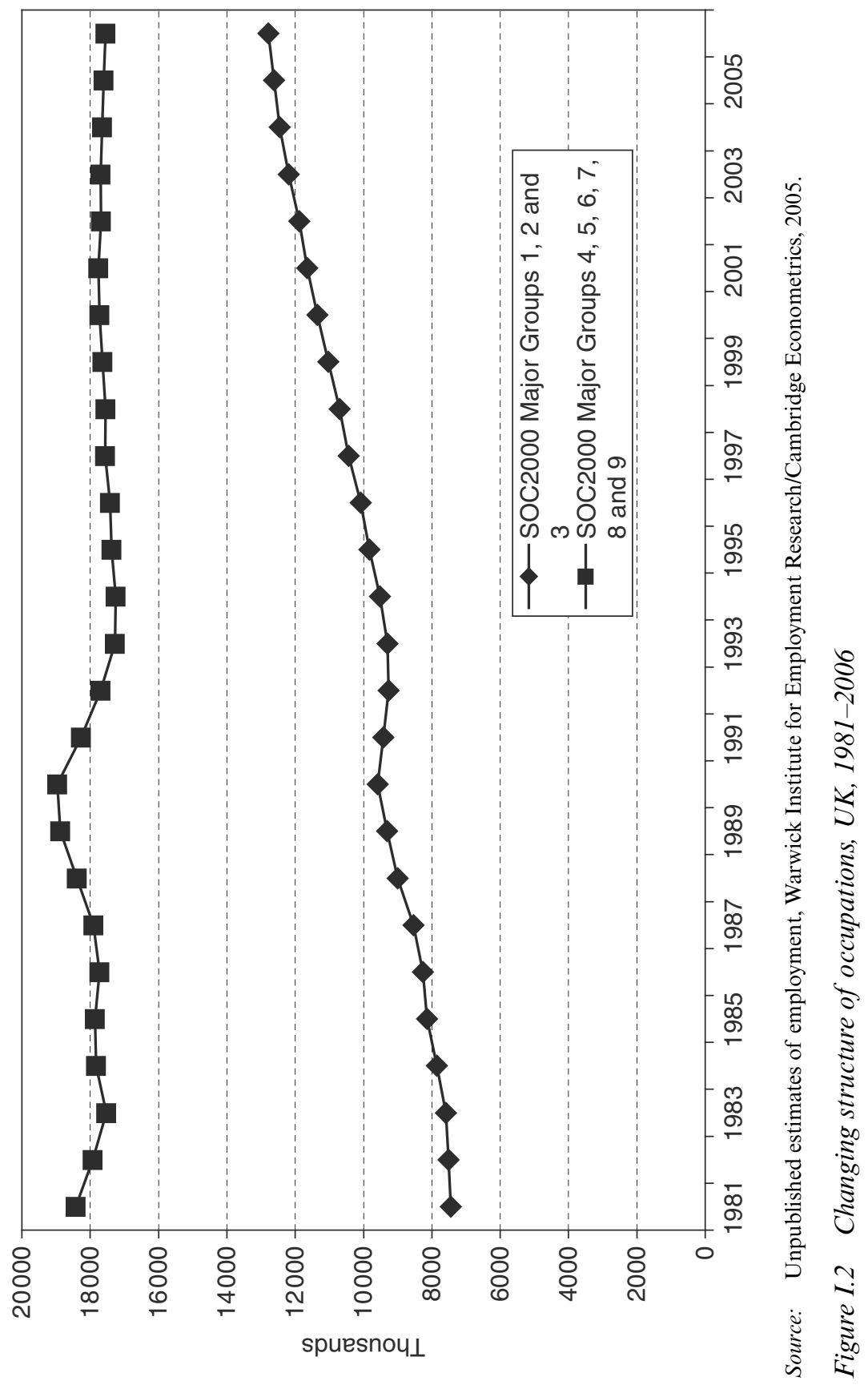


physical goods and low-level services. From a base of approximately 8 million jobs in the late 1980s, this group of occupations now covers over 12 million jobs in 2005. It is clear that the growth in the group of high level occupations is linked to the growth in full-time employment more generally.

Women were under-represented in the group of high level occupations in the early 1980s (Figure I. 3). Only 25 per cent of women were employed in this group in 1984, compared with 35 per cent of men. Since then, women have been catching up fast, with the corresponding ratios at 44 per cent for men and 38 per cent for women by 2004. Projections of employment by occupation indicate that this 'catch-up' is likely to continue, at least through the next decade.

Such growth would not have been possible without a corresponding increase in the acquisition of high-level qualifications associated with many of the jobs in this group of occupations. This coincided with the expansion of higher education generated by successive UK government and EU policies to raise skill levels, on the assumption that knowledge and technological sophistication rather than material resources will be the key to future success in the global economy (Figure I.4). The extent to which women would increasingly acquire the credentials to enable them to access these jobs was not anticipated in the 1980s.

The rate of increase of women's participation in higher education has been more than double that for men, such that women now outnumber men in part-time and full-time undergraduate and postgraduate studies (Table I.1).

With the benefit of hindsight, the quality of part-time employment as a significant constraint on women's employment opportunities was shortsighted. While underutilisation of part-time employees' skills remains a problem and a key research issue (see Chapter 2 in this volume; Grant et al. 2005), recent and ongoing research on graduate employment enables us to reassess the prospects for equality for women who have acquired the credentials to compete for opportunities in the 'knowledge economy'. It is here that we see the rapid growth in employment opportunities in general, with the growth of female full-time employment exceeding that for males.

The gaining of qualifications has been very noticeable among women in minority ethnic groups. Twenty-five years ago, it was not possible to examine minority ethnic differences in employment because of the shortage of data containing sufficient sample sizes of smaller minority ethnic groups. Recently, it has become possible to examine the separate minority ethnic groups' employment experiences, using Quarterly Labour Force Surveys (QLFS). 


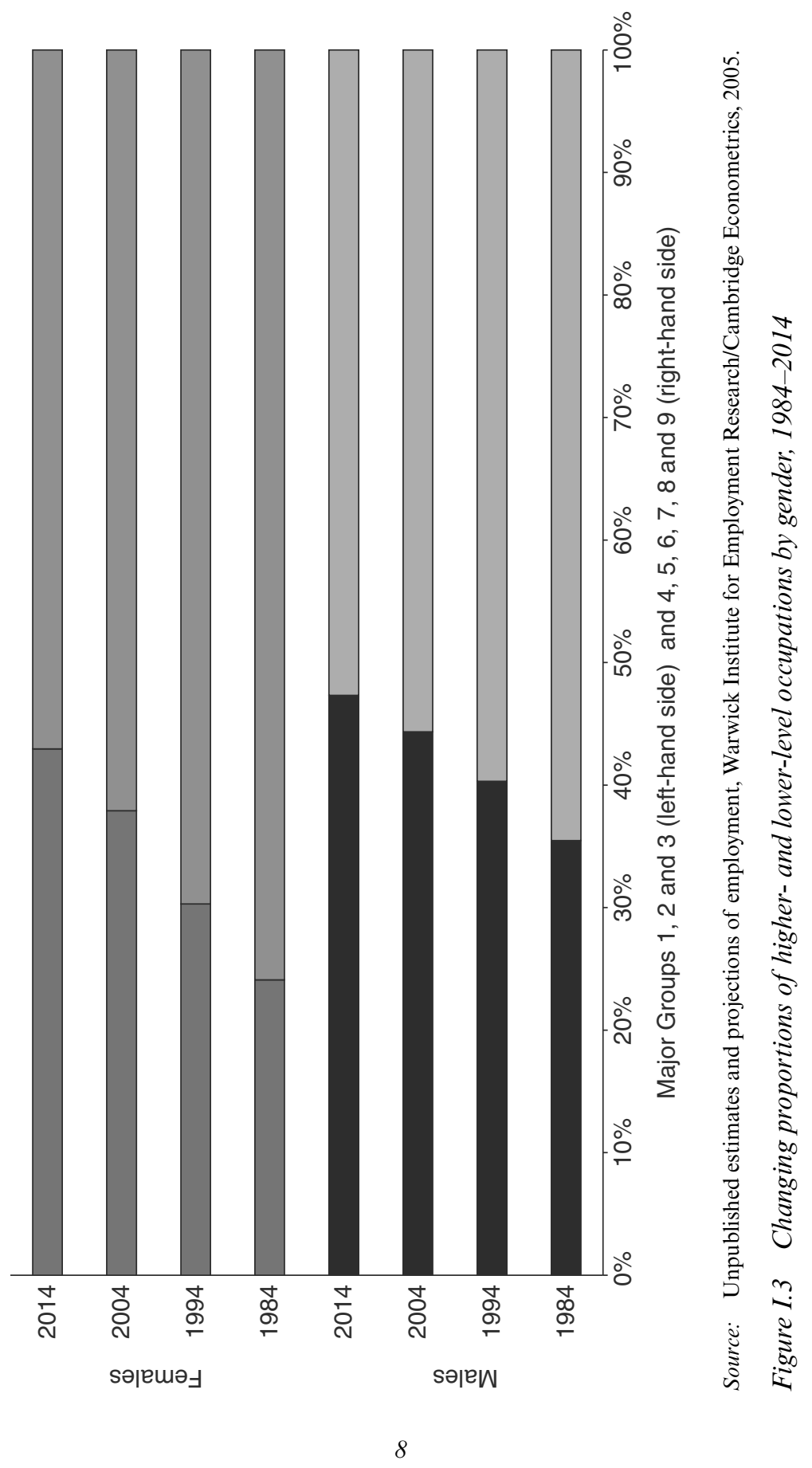




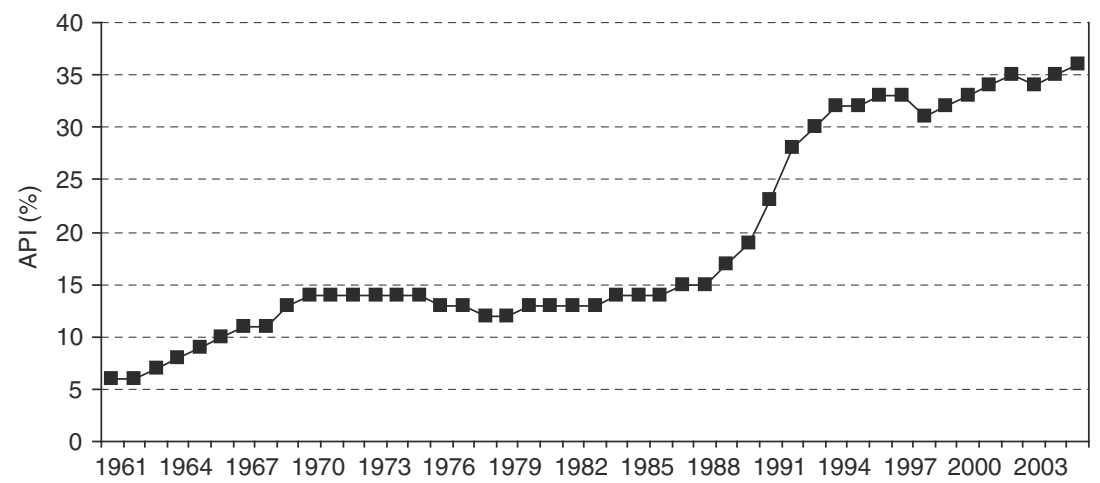

Note: * The Age Participation Index (API) measures the number of home-domiciled young (aged under 21) initial entrants to full-time and sandwich undergraduate courses, expressed as a proportion of the average 18- to 19-year-old Great Britain population.

Source: Elias and Purcell (2004).

Figure I. 4 Participation by young people in higher education, Age Participation Index (API), * Great Britain, 1961-2005

We are now able to see that enormous increases have taken place in the percentages of minority ethnic women of all groups, gaining degrees from the early 1990 s to the early 2000s (Table I.2) . This has had a large knockon effect to the overall employment rates of the higher qualified women from minority ethnic groups (Table I.3). It is clear that highly qualified women from minority ethnic groups have always had high employment rates relative to their unqualified peers. However, Black African women and Pakistani and Bangladeshi women also show large increases in the percentages employed over the 1990s decade, even when they were highly qualified.

\section{WHERE ARE WE NOW?}

In the first decade of the twenty-first century, we see a rather different picture: there is little difference in the percentage of married women (64 per cent) versus non-married women (62 per cent) in employment outside the home and almost 70 per cent of mothers with dependent children are working. Women now make up 45 per cent of the workforce, up from 38 per cent in 1971. The Equal Pay Act and the Sex Discrimination Act in the 1970s were important milestones in breaking down the barriers to women's participation in the labour market. But wages remain low in many occupations dominated by women and there is still a gap in mean hourly 
Table I.1 Students ${ }^{1}$ in higher education: ${ }^{2}$ by type of course and gender (UK, 1970/71-2000/01) (000s)

\begin{tabular}{|c|c|c|c|c|c|}
\hline & \multicolumn{2}{|c|}{ Undergraduate } & \multicolumn{2}{|c|}{ Postgraduate } & \multirow{2}{*}{$\begin{array}{l}\text { All in higher } \\
\text { education }\end{array}$} \\
\hline & Full-time & Part-time & Full-time & Part-time & \\
\hline \multicolumn{6}{|l|}{ Males } \\
\hline $1970 / 71$ & 241 & 127 & 33 & 15 & 416 \\
\hline 1980/81 & 277 & 176 & 41 & 32 & 526 \\
\hline 1990/91 & 345 & 193 & 50 & 50 & 638 \\
\hline 2000/01 & 511 & 228 & 82 & 118 & 940 \\
\hline Change & $212 \%$ & $180 \%$ & $248 \%$ & $787 \%$ & $226 \%$ \\
\hline \multicolumn{6}{|l|}{ 1970/71-2000/01 } \\
\hline \multicolumn{6}{|l|}{ Females } \\
\hline 1970/71 & 173 & 19 & 10 & 3 & 205 \\
\hline $1980 / 81$ & 196 & 71 & 21 & 13 & 301 \\
\hline 1990/91 & 319 & 148 & 34 & 36 & 537 \\
\hline $2000 / 01$ & 602 & 320 & 81 & 124 & 1128 \\
\hline Change & $348 \%$ & $1684 \%$ & $810 \%$ & $4133 \%$ & $550 \%$ \\
\hline $1970 / 71-2000 / 01$ & & & & & \\
\hline
\end{tabular}

Notes:

1 Home and overseas students.

2 At December each year. Includes Open University.

Sources: Department for Education and Skills; National Assembly for Wales; Scottish Executive; Northern Ireland Department for Employment and Learning.

earnings between men and women of 18 per cent for full-time workers and 40 per cent for those women working part-time.

As the Fawcett Society report Are We There Yet? 30 Years of Closing the Gap between Men and Women (2005) noted, women still experience 'sticky floors', meaning they get stuck at the bottom on the employment ladder clustered in low-paid jobs. So-called women's work such as caring, cleaning and catering is not valued, not paid well and has limited opportunities for training and promotion. Women also still experience 'glass ceilings'. The lack of acceptance that senior jobs can be done on a flexible basis combines with discrimination to stop women with family responsibilities reaching senior positions.

However, the picture is complex. Increasing proportions of women have been gaining educational qualifications, with women's participation levels in UK higher education now exceeding men's. Graduates now work in a much wider range of occupations than was the case 25 years ago and a high 
Table I.2 Percentage of women in each ethnic group (a) with a degree and (b) without any qualifications, 1992 to 2003

\begin{tabular}{|c|c|c|c|c|c|c|}
\hline & \multicolumn{3}{|c|}{$1992-95$} & \multicolumn{3}{|c|}{$2000-03$} \\
\hline & $\begin{array}{l}\text { With a } \\
\text { degree }\end{array}$ & $\begin{array}{c}\text { No } \\
\text { qualifications }\end{array}$ & Number & $\begin{array}{l}\text { With a } \\
\text { Degree }\end{array}$ & $\begin{array}{c}\text { No } \\
\text { qualifications }\end{array}$ & Number \\
\hline White & 17.7 & 30.9 & 134136 & 26.8 & 19.7 & 115290 \\
\hline Black & 19.3 & 28.4 & 1650 & 28.4 & 14.8 & 1558 \\
\hline \multicolumn{7}{|l|}{$\begin{array}{l}\text { Caribbean and } \\
\text { Other }\end{array}$} \\
\hline Black African & 22.2 & 23.4 & 603 & 33.7 & 17.0 & 941 \\
\hline Indian & 15.4 & 40.9 & 2297 & 28.5 & 23.8 & 2194 \\
\hline $\begin{array}{l}\text { Pakistani and } \\
\text { Bangladeshi }\end{array}$ & 5.7 & 61.5 & 1469 & 13.1 & 46.8 & 1769 \\
\hline $\begin{array}{l}\text { Chinese and } \\
\text { other }\end{array}$ & 22.3 & 28.5 & 1649 & 31.4 & 18.5 & 2472 \\
\hline Total & 17.7 & 31.3 & 141804 & 26.8 & 20.1 & 124224 \\
\hline
\end{tabular}

Notes: For women age 19-60, excluding full-time student. Data are unweighted. 'Degree' refers to first or higher degree or equivalent.

Source: Quarterly Labour Force Survey Spring Quarters for GB, from Lindley et al. (2006).

proportion of these occupations involve the production, management or transfer of knowledge or information. To a large extent, this is because the nature of work has changed in ways that have both stimulated and accommodated the substantial expansion in higher education. In some areas of work this reflects the growth of sectors and occupations that make use of graduates (for example, the information and communication technology sector, environmental and social welfare occupations). In other areas it relates to the perceived need within organisations to recruit those who have relevant high-level qualifications into occupations where no such pool of highly qualified labour previously existed (for example, the wide range of junior and middle management and administrative jobs for which graduates are now recruited). In part it stems from the growth of particular occupational specialisms (for example, in many areas of health care, education, construction, engineering and technical sales). A pathway through higher education is becoming the de facto standard for entry into these occupations. Nevertheless, the longitudinal evidence in the paper by Purcell and Elias in this volume (Chapter 1) indicates that work-life balance choices and organisational obstacles continue to restrict the career progression of many highly qualified women. 
Table I.3 Percentage of women employed by minority ethnic group and degree/without a degree

\begin{tabular}{|c|c|c|c|c|c|c|}
\hline & \multicolumn{3}{|c|}{$1992-95$} & \multicolumn{3}{|c|}{$2000-03$} \\
\hline & $\begin{array}{l}\text { With a } \\
\text { degree }\end{array}$ & $\begin{array}{l}\text { Without } \\
\text { a degree }\end{array}$ & All & $\begin{array}{l}\text { With a } \\
\text { degree }\end{array}$ & $\begin{array}{l}\text { Without } \\
\text { a degree }\end{array}$ & All \\
\hline White & $84.5^{*}$ & $65.4^{*}$ & 68.8 & $87.2 *$ & $68.2 *$ & $73.3^{*}$ \\
\hline Black & 84.6 & 58.6 & 63.6 & 85.3 & 59.3 & 66.7 \\
\hline $\begin{array}{l}\text { Caribbean } \\
\text { and other }\end{array}$ & & & & & & \\
\hline Black African & 70.9 & 45.8 & 51.4 & 79.8 & 47.0 & $58.0^{*}$ \\
\hline Indian & 84.1 & 55.6 & 60.0 & 84.4 & 56.4 & $64.4^{*}$ \\
\hline $\begin{array}{l}\text { Pakistani and } \\
\text { Bangladeshi }\end{array}$ & $55.9^{*}$ & 16.97 & 19.2 & $72.0^{*}$ & 17.6 & $24.8^{*}$ \\
\hline $\begin{array}{l}\text { Chinese and } \\
\text { other }\end{array}$ & 79.4 & 48.3 & 55.3 & 77.2 & 48.8 & 57.7 \\
\hline Total & $84.2^{*}$ & $64.3 *$ & 67.8 & $86.8^{*}$ & $66.5^{*}$ & $71.9^{*}$ \\
\hline
\end{tabular}

Notes:

For women age 19-60, excluding full time students. Data are unweighted.

'Degree' refers to first or higher degree or equivalent.

* Denotes a statistical significance between the two means for period $1992-95$ and period 2000-03.

Source: QLFS Spring Quarters for GB, reproduced from Lindley et al. (2006).

\section{WHERE TO NEXT?}

The Women and Work Commission (2006) concluded its report Shaping a Fairer Future, with several recommendations regarding ways of increasing employment opportunities for women and reducing the gender pay gap, including flexible working, affordable childcare and quality part-time work. Some felt the Commission 'lacked teeth' in not recommending the mandatory monitoring of gender pay and promotion (see Deakin and McLaughlin, Chapter 13 in this volume) but the Commission does applaud the new Gender Duty that requires the public sector to actively promote gender equality. The Commission emphasised that making progress on the gender pay gap is a key priority not only because barriers that prevent the utilisation of women's talent and skills in the labour market are economically costly for the UK economy, but also because women have the right to expect a fair deal in the labour market.

In this book we try to break down some of the artificial barriers that have plagued the understanding of changing women's lives. One such 
barrier is the way that employment studies are often separated off from family research as if the two do not interrelate. Another, and one that we hope our book title does not perpetuate, is the way concerns about gender inequality are often taken to mean an exclusive focus on women, whereas men's and women's lives are so interlinked that it is essential to examine the ways that male and female interconnected work and family lives, unfold over time.

Underlying many of the changes in reproduction over the past half century is the demise of the male breadwinner family. This has brought something of a paradigm shift in gender relations, but it is not clear whether the shift brings more or less equality. The expectation on the part of UK and EU policy-makers today is increasingly that women will be fully 'individualised' in the sense of economically autonomous, although policies are often ambiguous on this score. Social reality and individuals preferences, however, sometimes tell a different story; women are still disproportionately in part-time employment and still do the bulk of unpaid care work. There are lots of puzzles, for example, shifts in gender equality have been very uneven across ethnic groups, age and geographical regions, and often far slower than many of the conventional theories of human capital would suggest. The gender wage gap has proved stubborn and new pay inequalities between women are emerging. The life chances of women, men and children are increasingly polarised by educational attainment, but it is far from clear whether and under what circumstances a convergence in human capital will result in reductions of gender inequalities.

The interface between social science and policy is not an easy one. Portes (2000) is surely right to insist that social science's contribution to the building of a just society lies in careful analyses of social processes, awareness of their concealed and unintended manifestations, and sustained efforts to understand the interplay between actors and their situations. All the contributors to this book are keen, where possible, to draw out the implications of their research in ways that can inform policy. Yet there are ongoing tensions between enhancing individual or group rights and sustaining an effective and productive labour force and society. Maternity and paternity provision is a case in point, where the 'rights' of mothers, fathers and children may be at odds with each other, and in further tension with the goals of employment organisations. Migrants' rights are another complex issue, where there is huge difficulty in balancing the rights of the individuals with the collective logic required to fund and sustain employment protection and welfare benefits. The business case for improving employment opportunities and promoting greater equality in women's employment is overwhelming, but it would be foolish to deny that women will remain 
disadvantaged in the labour force for as long as the share of family care between men and women remains so uneven.

\section{ORGANISATION AND OVERVIEW}

The majority of the contributing authors to this volume are part of an ongoing research network on Gender Inequalities (GeNet) that has been funded by the Economic and Social Research Council to look at inequality in production and reproduction (Scott 2004). The network consists of nine interlinked research projects that together are pursuing the common goal of examining the way men's and women's work and family lives are changing and how policy can intervene effectively to promote change towards greater equality. Part I contains three chapters assessing the progress that has been made towards greater equality in the employment of women. Purcell and Elias look at the case of graduates in the knowledge economy and pinpoint some of the particular work-family balance issues that affect highly educated women and men. Dex et al. examine how far occupational mobility has changed between 1980 and 2005 and they show how the penalties to occupational status of spending time out of the labour force have increased for more recent generations. Dale et al. illustrate the importance of ethnic differences in labour force activity and highlight how the career benefits of education differ across different ethnic groups. Part II deals with the dynamic process of employment and family across the life course. Martin and Roberts look back on the substantive questions and methodological challenges that faced the 1980 Women and Employment Survey. Ermisch examines how cohabitation, which in 1980 was relatively rare, has produced the explosion of childbearing outside of marriage as the practice has spread from the better educated to the less educated population. Scott examines changing gender role attitudes and suggests that there is both a shift towards greater egalitarianism and greater acknowledgement of the family strain that can result from the dual earner norm. Work-life balance is tackled head-on in Part III, with McRae considering the benefits and costs of fulltime work for mothers. Fagan et al. utilise a qualitative study to explore how the time pressures that mothers face in juggling parenting and employment differs by social class. This theme of class differences in work-life conflict is further explored through quantitative analysis across time by Crompton and Lyonette. Harkness traces the continued importance of gender stereotypes in the division of paid and unpaid labour within households. Lewis examines how the logic driving policy change on work-family balance has shifted under New Labour in the UK, arguing that as an explicit policy driver gender equality has taken a back seat. 
So what is the way forward? In the Part IV, Rubery showcases best practice from a range of European countries that have sought to modernise labour market institutions to enhance greater gender equality. Deakin and McLaughlin examine, with reference to the gender pay gap, how far 'reflexive law', which relies on self-regulatory mechanisms rather than mandatory legislation, is likely to achieve greater equality. McDowell et al. illustrate the way transnational movements in employment are changing the experience of women workers at the start of the new millennium. Himmelweit looks specifically at whether policies on care help or hinder gender equality and she illustrates the potential dilemmas, for example, when affordable care for some women means low pay for other women who provide care. Policies often adopt a position of gender neutrality, but the realities of women's and men's experiences of paid and unpaid work make it clear that gender equality remains a pressing challenge.

\section{REFERENCES}

Dex, S. and L. Shaw (1986), British and American Women at Work: Do Equal Opportunities Policies matter?, London: Macmillan.

Elias, P. and K. Purcell (1988), 'Women and paid work: prospects for equality', in A. Hunt (ed.), Women and Paid Work, Basingstoke: Macmillan.

Fawcett Society (2005), Are We There Yet? 30 Years of Closing the Gap between Men and Women, London: Fawcett Society.

Grant, L., S. Yeandle and L. Buckner (2005), 'Working below potential: women and part-time work', Equal Opportunities Commission, Working Paper No. 40, EOC, Manchester.

Lindley, J., A. Dale and S. Dex (2006), 'Ethnic differences in women's employment: the changing role of qualifications', Oxford Economic Papers, 58(2), 351-78.

Main, B. and P. Elias (1987), 'Women returning to paid employment', International Review of Applied Economics, 1(1), 86-108.

Martin, J. and C. Roberts (1984), Women and Employment - a Life Time Perspective, London: HMSO.

Portes, A. (2000), 'Presidential address: the hidden abode: sociology as analysis of the unexpected', American Sociological Review, 65(1), 1-18.

Scott, J. (2004), 'Gender inequality in production and reproduction: a new priority research network', GeNet Working Papers, No. 1. Available at www.genet. ac.uk/workpapers/GeNet2004p1.pdf (accessed 7 January 2008).

Women and Work Commission (2006), Shaping a Fairer Future, London: Women and Equality Unit.

Wright, R. and J. Ermisch (1991), 'Gender discrimination in the British labour market: a reassessment’, Economic Journal, 101(406), 508-22. 
Jacqueline Scott, Shirley Dex, Heather Joshi, Peter Elias, and Kate Purcell - 9781848442931 Downloaded from PubFactory at $04 / 26 / 2023$ 07:39:56AM 